\title{
Functional fermented sausages incorporated with microencapsulated Lactobacillus plantarum BG 112 in Acrycoat S100
}

\author{
Lia Inês Machado Vasconcelos ${ }^{\mathrm{a}, \mathrm{d}}$, Rosana Aparecida da Silva-Buzanello ${ }^{\mathrm{a}}$, \\ Daneysa Lahis Kalschne ${ }^{\text {b, }}$, Fernando Reinoldo Scremin ${ }^{c}$, Paulo Rodrigo Stival Bittencourt ${ }^{c}$, \\ Joaquina Teresa Gaudêncio Dias ${ }^{\mathrm{d}}$, Cristiane Canan ${ }^{\mathrm{b}}$, Marinês Paula Corso ${ }^{\mathrm{b}}$ \\ ${ }^{a}$ Departamento Acadêmico de Alimentos (DAALM), Universidade Tecnológica Federal Do Paraná, Campus Medianeira (UTFPR-MD), Avenida Brasil 4232, CEP: \\ 85884-000, Medianeira, Paraná, Brazil \\ b Programa de Pós-graduação Em Tecnologia de Alimentos (PPGTA), Universidade Tecnológica Federal Do Paraná, Campus Medianeira (UTFPR-MD), Avenida Brasil \\ 4232, CEP: 85884-000, Medianeira, Paraná, Brazil \\ ${ }^{\mathrm{c}}$ Laboratório de Análises Térmicas e Espectrométricas de Combustíveis e Materiais (LATECOM), Departamento Acadêmico de Química (DAQUI), Universidade \\ Tecnológica Federal Do Paraná, Campus Medianeira (UTFPR-MD), Avenida Brasil 4232, CEP: 85884-000, Medianeira, Paraná, Brazil \\ ${ }^{\mathrm{d}}$ Escola Superior Agrária, Instituto Politécnico de Bragança, Campus de Santa Apolónia, 5300-253, Bragança, Portugal
}

\section{A R T I C L E I N F O}

\section{Keywords:}

Central composite rotatable design

Paired-preference test

Thermal analysis

Probiotic salami

\begin{abstract}
A B S T R A C T
The development of functional meat products is an innovative trend aiming to meet consumer demand. Microencapsulation is a promising alternative to ensure probiotic viability, mainly when the wall material resists the adverse extrinsic conditions releasing the probiotics into the intestine. Therefore, Lactobacillus plantarum was encapsulated in Acrycoat S100 by spray drying. The encapsulation process was analysed using a central composite rotatable design (CCRD), varying the encapsulant and probiotic microorganism concentrations to evaluate the microcapsule yield and encapsulation efficiency (EE). L. plantarum microcapsules added to a Milano-type salami formulation for a probiotic product were characterised by physicochemical and morphological analysis, and compared to a control. CCRD central points (5\% encapsulant and $1 \%$ probiotic) showed the highest yield (above 35\%) and EE (above 78\%) values. The optimum microcapsule formulation was obtained with $5.57 \%$ encapsulant and 1\% probiotic, achieving 80.9\% EE. FTIR-ATR and thermal analysis showed efficient microorganisms entrapment in the microcapsules, increasing their thermal stability in optimised assays. Milano-type probiotic salami was obtained with $8 \log \mathrm{CFU} \mathrm{g} \mathrm{g}^{-1} \mathrm{LAB}$ counts. Physicochemical and sensory properties did not differ for salami formulations and ensured their good acceptance, demonstrating $\mathrm{pH}$-dependent controlled release advantages compared to a usual probiotic product.
\end{abstract}

\section{Introduction}

Probiotics are live microbial feed supplements with health benefits to the host when ingested in adequate amounts (Basu, Banerjee, Chowdhury, \& Bhattacharya, 2018; Bultosa, 2015; FAO \& WHO, 2006). Immune system stimulation, nutrient and vitamin B absorption enhancement, digestive and protective enzyme production, intestinal mucosa barrier strengthening, diarrhoea occurrence reduction, intestinal motility stimulation, reduced constipation, lactose intolerance symptoms relief (due to better use of this disaccharide), colon cancer prevention or suppression, cholesterol levels decrease, and anticarcinogenic effects have been reported in individuals using probiotics
(Ambalam, Raman, Purama, \& Doble, 2016; Dubey, Ghosh, Bishayee, \& Khuda-Bukhsh, 2016).

Probiotics should be able to activate themselves and quickly grow, remaining in the intestines for some time, resisting antibiotics found in food, but sensitive to those used in lactic acid treatments and to the absence of pathogenic, toxic, and allergenic reactions. Moreover, probiotics must survive the journey through the digestive system and multiply easily upon reaching the intestines. Furthermore, probiotics are required to maintain extreme gastrointestinal system conditions, such as $\mathrm{pH}$, gastric enzymes, and bile salts (Yao et al., 2020). Lactic acid bacteria (LAB) represent the leading probiotic group, especially the Lactobacillus genus, including L. plantarum (Bultosa, 2015; FAO \& WHO, 2006).

\footnotetext{
* Corresponding author.

E-mail addresses: daneysa@hotmail.com, daneysa@yahoo.com.br (D.L. Kalschne).
} 
Microencapsulation is a promising alternative for probiotic viability. The wall material in the encapsulation process must resist adverse conditions such as exposure to extrinsic microorganisms, protecting the culture until the probiotic is released into the intestines to perform its beneficial functions (Yao et al., 2020). There has been significant interest in using biocompatible polymers in microencapsulation as they are easily moulded into micrometric particles, enabling encapsulated compound release to specific sites in the human body (Menezes et al., 2018). Acrycoat S100 is produced by methacrylic acid and methyl methacrylate copolymerisation. It has been applied to microencapsulated drug protection due to its gastroresistance or insolubility at neutral and acidic $\mathrm{pH}$ values. Compounds such as water and acids cannot solubilise it, reaching the intestines, where it will be solubilised at alkaline $\mathrm{pH}$, releasing the encapsulated material (Colomé, Raffin, Jornada, Pohlmann, \& Guterres, 2007). Acrycoat S100 may be considered a new wall material for food applications, releasing the core in intestinal $\mathrm{pH}$ with potential applications in complex food matrices such as meat products.

Convenience, stability, sensory aspects, and nutritional value have been attributed to fermented meat characterising it as an essential constituent for the human diet. The growing market demand for functional foods has been reported mainly by consumers' concern for healthy products (Pavli, Argyri, Chorianopoulos, Nychas, \& Tassou, 2020). In this regard, functional meat products development is an excellent alternative for probiotic microorganisms' incorporation. However, the complexity of meat and probiotic sensitivity to the process conditions, as well as the additives used in the industrial production, may affect the probiotic growth and viability, as well as $\mathrm{pH}$, acidity, the presence of other microorganisms (native microflora of meat), water activity, processing, storage temperature, additives (nitrite, and nitrate) and salt concentrations, protein matrix composition, and low natural sugars content (Aspri, Papademas, \& Tsaltas, 2020). Microencapsulation is characterised as the solution for the inherent harmful attributes of meat products for probiotic viability. To the best of our knowledge, fermented sausage as a vehicle of probiotic encapsulated in Acrycoat S100 has not been reported in the literature, demonstrating innovation in the area.

This study aimed (1) to evaluate $L$. plantarum microencapsulation in Acrycoat S100 by spray drying (2) incorporating the microencapsulated bacteria in Milano-type salami to obtain a probiotic product. Its effect on microbiological, chemical, physicochemical, and sensory properties was evaluated and compared to control salami (without microcapsules).

\section{Materials and methods}

\subsection{Material}

Poly (methacrylic acid-co-methyl methacrylate) (Acrycoat S100 type B (1:2), 125,000 g/mol, Corel Pharma Chem, Gujarat, India) was used as the wall material. Tween-80 (Synth, Diadema, Brazil) was used as the surfactant. Distilled water and sodium bicarbonate (Alphatec, São Paulo, Brazil) were used for buffer solution preparation as a continuous phase of suspension. DeMan, Rogosa and Sharpe (MRS) broth (Merck, Darmstadt, Germany), MRS agar (Merck), plate count agar (PCA) (Himedia, Mumbai, India), and bacteriological meat peptone (MicroMed, Rio de Janeiro, Brazil) were used for the microbiological analysis.

Freeze-dried L. plantarum BG112 culture (Sacco, Campinas, Brazil) was preactivated $\left(0.1 \% \mathrm{w} \mathrm{v}^{-1}\right)$ in MRS broth and incubated for $6 \mathrm{~h}$ at $30{ }^{\circ} \mathrm{C}$. Preactivated microorganism aliquots $(5 \%)$ were transferred to Erlenmeyer flasks containing MRS broth and incubated for $12 \mathrm{~h}$ at $30^{\circ} \mathrm{C}$ (until the stationary phase). Such step was repeated twice for incubation and reincubation. The final culture was freeze-dried $\left(25 \pm 1{ }^{\circ} \mathrm{C} / 0.050\right.$ $\mathrm{mBar}$ ) and stored in plastic flasks at $-18^{\circ} \mathrm{C}$. The total $\mathrm{LAB}$ count was 14 $\log$ CFU g ${ }^{-1}$.

\subsection{Experimental design}

Central composite rotatable design (CCRD) was performed to optimise the microencapsulation process. Acrycoat $\mathrm{S} 100\left(x_{1}\right)$ and L. plantarum $\left(x_{2}\right)$ concentrations were evaluated for yield $\left(y_{1}\right)$ (total microorganism content after microencapsulation) and encapsulation efficiency (EE) $\left(y_{2}\right)$ (Table 1).

\subsection{L. plantarum microencapsulation}

L. plantarum was suspended in sterilised distilled water $(50 \mathrm{~mL})$ supplemented with Tween-80 (0.18 g) under magnetic stirring (752 A, Fisatom, São Paulo, Brazil) for $30 \mathrm{~min}$. Acrycoat $\mathrm{S} 100$ was dissolved into a $150 \mathrm{~mL}$ sterilised sodium bicarbonate buffer solution $1 \mathrm{M}(\mathrm{pH} \cong 8.6)$ under magnetic stirring for $30 \mathrm{~min}$. The L. plantarum suspension was transferred to an Acrycoat S100 solution and stirred at $700 \mathrm{rpm}$ for 30 min using a homogeniser (713D, Fisatom, São Paulo, Brazil).

The spray drying suspension was performed in a mini spray dryer (MSD 1.0, Labmaq, São Paulo, Brazil) using a $500 \mathrm{~mm} \times 150 \mathrm{~mm}$ drying chamber with a $0.7 \mathrm{~mm}$ opening twin fluid nozzle atomiser. A peristaltic pump was used at a $0.6 \mathrm{~L} \mathrm{~h}^{-1}$ flow rate for feeding, $84 \pm 1{ }^{\circ} \mathrm{C}$ inlet air temperature, and a $42 \pm 1{ }^{\circ} \mathrm{C}$ outlet temperature, with a $35 \mathrm{Nm}^{3} \mathrm{~h}^{-1}$ (standard cubic meter per hour) drying air flow rate. The microcapsules were collected in plastic flasks and stored at $4 \pm 1{ }^{\circ} \mathrm{C}$.

\subsection{Microcapsule characterisation}

\subsubsection{Microcapsule yield}

The LAB count determined the total microorganism content $\left(N_{1}\right)$ in the microcapsules (encapsulated and non-encapsulated - adhered to the outer part of the microcapsule surface). For each assay, $1 \mathrm{~g}$ microcapsules were added to a tube with $9 \mathrm{~mL}$ sodium bicarbonate buffer solution $1 \mathrm{M}(\mathrm{pH} \cong 8.6)$ and stirred for $5 \mathrm{~min}$. Serial dilutions were then prepared and a $1 \mathrm{~mL}$ aliquot was mixed with molten MRS agar and poured into a petri dish. After agar solidification, MRS was poured, forming a top layer. The plates were incubated inverted at $30^{\circ} \mathrm{C}$ for $48 \mathrm{~h}$ (Kalschne et al., 2015). The yield was calculated according to Equation (1) (Picot \& Lacroix, 2004).

Yield $(\%)=\left(N_{l} / N_{0}\right) \times 100$

$N_{O}$ is the initial LAB count of the culture added to the formulations, and $N_{1}$ is the total LAB count ( $\mathrm{CFU} \mathrm{g}{ }^{-1}$ ) in the microcapsule obtained (encapsulated and non-encapsulated microorganisms).

\subsubsection{Encapsulation efficiency (EE)}

The non-encapsulated microorganisms were quantified to determine the microcapsule EE. Microcapsules $(1 \mathrm{~g})$ were placed in a tube with 9 $\mathrm{mL}$ sterile peptone water $(0.1 \%)$ vortex-stirred for $1 \mathrm{~min}$ as per steps described in section 2.4.1. Encapsulation efficiency was calculated according to Equation (2) (Picot \& Lacroix, 2004).

$E E(\%)=\left(N_{1}-N_{2}\right) / N_{l} \times 100$

$N_{1}$ is the total LAB count (CFU $\mathrm{g}^{-1}$ ) in microcapsules obtained (encapsulated and non-encapsulated microorganisms), and $N_{2}$ is a nonencapsulated LAB count.

\subsubsection{Physical property determinations}

Moisture was determined at $105^{\circ} \mathrm{C} \pm 2{ }^{\circ} \mathrm{C}$ up to constant weight in a drying oven (q313 m, Quimis, São Paulo, Brazil) and expressed as g 100 $\mathrm{g}^{-1}$ (AOAC, 2005). Water activity was measured based on the dew point using a water activity analyser (4 TE, Aqualab, São Paulo, Brazil) at $25{ }^{\circ} \mathrm{C}$. Hygroscopicity was determined using approximately $1 \mathrm{~g}$ microcapsules placed in an airtight glass container with $\mathrm{NaCl}$ saturated solution $(75.3 \% \mathrm{RH})$ at $25{ }^{\circ} \mathrm{C}$ for each assay. After one week, the samples were weighed and their hygroscopicity expressed as $g$ of water absorbed 
Table 1

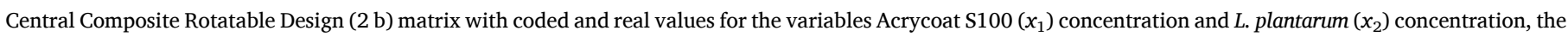
responses yield $\left(y_{1}\right)$ and encapsulation efficiency $\left(y_{2}\right)$, and microcapsule physical properties-moisture, water activity, hygroscopicity, and microcapsules size.

\begin{tabular}{|c|c|c|c|c|c|c|c|c|}
\hline \multirow[t]{2}{*}{ Runs } & \multirow[t]{2}{*}{$x_{1}(\%)$} & \multirow[t]{2}{*}{$x_{2}(\%)$} & \multirow[t]{2}{*}{$\mathrm{y}_{1}(\%)$} & \multirow[t]{2}{*}{$y_{2}(\%)$} & \multirow{2}{*}{$\frac{{ }^{1} \text { Moisture }}{\left({\left.\mathrm{g} 100 \mathrm{~g}^{-1}\right)}\right.}$} & \multirow[t]{2}{*}{${ }^{1}$ Water activity } & \multirow{2}{*}{$\frac{{ }^{1} \text { Hygroscopicity }}{\left(\mathrm{g}_{\text {water absorbed }} 100 \mathrm{~g}^{-1} \text { ) }\right.}$} & \multirow[t]{2}{*}{${ }^{2}$ Size $(\mu \mathrm{m})$} \\
\hline & & & & & & & & \\
\hline 1 & $-1(2.2)$ & $-1(0.6)$ & $6.5 \pm 0.5$ & $26.6 \pm 0.3$ & $4.93 \pm 0.06^{\mathrm{cd}}$ & $0.27 \pm 0.01^{\mathrm{h}}$ & $23.86 \pm 1.73^{\mathrm{b}}$ & $4.49 \pm 3.41^{\mathrm{de}}$ \\
\hline 2 & $+1(7.8)$ & $-1(0.6)$ & $0.5 \pm 0.0$ & $17.6 \pm 1.3$ & $2.89 \pm 0.07^{g}$ & $0.31 \pm 0.00^{\mathrm{fg}}$ & $7.64 \pm 0.78^{\mathrm{e}}$ & $4.97 \pm 2.10^{\text {cde }}$ \\
\hline 3 & $-1(2.2)$ & $+1(1.4)$ & $23.6 \pm 0.8$ & $8.0 \pm 2.2$ & $5.89 \pm 0.13^{b}$ & $0.32 \pm 0.01^{\mathrm{ef}}$ & $18.16 \pm 0.00^{c}$ & $4.80 \pm 2.35^{\text {cde }}$ \\
\hline 4 & $+1(7.8)$ & $+1(1.4)$ & $10.6 \pm 0.4$ & $56.5 \pm 0.0$ & $2.86 \pm 0.14^{g}$ & $0.29 \pm 0.00^{g}$ & $9.28 \pm 0.22^{\mathrm{e}}$ & $6.75 \pm 3.26^{\mathrm{a}}$ \\
\hline 5 & $-1.41(1.0)$ & $0(1.0)$ & $10.3 \pm 1.4$ & $25.3 \pm 3.2$ & $4.93 \pm 0.06^{\mathrm{a}}$ & $0.25 \pm 0.01^{\mathrm{h}}$ & $32.65 \pm 0.19^{\mathrm{a}}$ & $4.55 \pm 1.60^{\text {cde }}$ \\
\hline 6 & $+1.41(9.0)$ & $0(1.0)$ & $1.5 \pm 0.5$ & $45.9 \pm 3.0$ & $3.51 \pm 0.10^{\mathrm{e}}$ & $0.36 \pm 0.01^{\mathrm{c}}$ & $8.11 \pm 0.19^{\mathrm{e}}$ & $5.55 \pm 2.78^{\mathrm{bcd}}$ \\
\hline 7 & $0(5.0)$ & $-1.41(0.4)$ & $0.6 \pm 0.0$ & $43.3 \pm 3.0$ & $4.10 \pm 0.16^{\mathrm{f}}$ & $0.34 \pm 0.00^{c}$ & $12.56 \pm 0.03^{\mathrm{d}}$ & $4.38 \pm 1.65^{\mathrm{e}}$ \\
\hline 8 & $0(5.0)$ & +1.41 (1.6) & $2.6 \pm 0.0$ & $2.5 \pm 0.3$ & $4.46 \pm 0.11^{\mathrm{df}}$ & $0.39 \pm 0.01^{\mathrm{b}}$ & $12.94 \pm 0.28^{\mathrm{d}}$ & $5.66 \pm 3.52^{\mathrm{abc}}$ \\
\hline 9 & $0(5.0)$ & $0(1.0)$ & $37.1 \pm 0.9$ & $80.0 \pm 0.2$ & $4.97 \pm 0.15^{c}$ & $0.41 \pm 0.01^{\mathrm{ab}}$ & $9.00 \pm 0.04^{\mathrm{e}}$ & $4.75 \pm 2.91^{\mathrm{cde}}$ \\
\hline 10 & $0(5.0)$ & $0(1.0)$ & $39.3 \pm 3.3$ & $80.6 \pm 0.8$ & $5.01 \pm 0.08^{\mathrm{c}}$ & $0.41 \pm 0.00^{\mathrm{a}}$ & $9.30 \pm 0.20^{\mathrm{e}}$ & $4.69 \pm 2.64^{\text {cde }}$ \\
\hline 11 & $0(5.0)$ & $0(1.0)$ & $35.8 \pm 2.8$ & $78.2 \pm 1.3$ & $5.00 \pm 0.10^{c}$ & $0.41 \pm 0.00^{\mathrm{a}}$ & $8.99 \pm 0.29^{\mathrm{e}}$ & $4.72 \pm 2.37^{\text {cde }}$ \\
\hline 12 & $0.2(6.4)$ & $0(1.0)$ & $34.9 \pm 3.5$ & $80.9 \pm 2.1$ & $5.28 \pm 0.15^{c}$ & $0.34 \pm 0.00^{\mathrm{ce}}$ & $13.13 \pm 0.63^{\mathrm{d}}$ & $6.34 \pm 2.17^{\mathrm{ab}}$ \\
\hline
\end{tabular}

Different letters in same column indicate significant difference among the assays by the Tukey test $(\mathrm{P} \leq 0.05)$.

Means \pm standard deviation $(\mathrm{n}=3)$.

Means \pm standard deviation $(\mathrm{n}=120)$

per $100 \mathrm{~g}$ dry-basis microcapsules (Fritzen-Freire et al., 2012). All determinations were performed in duplicate.

\subsubsection{Morphology and microcapsule size}

Morphology and microcapsule size were characterised by scanning electron microscopy (SEM) (Quanta 200, Philips/FEI, Hillsboro, USA). Microcapsules from each assay were sputter-coated with gold ( $\cong 15 \mathrm{~nm})$ for $98 \mathrm{~s}$ at $40 \mathrm{~V}$ and then observed using SEM. The average size of microcapsules was calculated by measuring 120 particles for each assay (Fritzen-Freire et al., 2012).

\subsubsection{Fourier transform infrared (FTIR-ATR) spectroscopy}

The microcapsules obtained and the pure materials - L. plantarum culture and Acrycoat S100 - were analysed by FTIR spectroscopy (Spectrum $100 \mathrm{~S}$, Frontier PerkinElmer) using an attenuated reflectance mode (ATR). The FTIR-ATR spectra were recorded within a 4000-700 $\mathrm{cm}^{-1}$ spectral range at 10 scans per spectrum with a $4 \mathrm{~cm}^{-1}$ spectral resolution.

\subsubsection{Thermal analyses}

Thermogravimetric (TG) and differential scanning calorimetric (DTA) analyses were performed using a thermoanalyser (STA 6000, PerkinElmer). Approximately $10 \mathrm{mg}$ microcapsules and pure material samples were placed in a platinum crucible and heated from 50 to $600{ }^{\circ} \mathrm{C}\left(10^{\circ} \mathrm{C} \mathrm{m^{-1 } )}\right.$ under a nitrogen atmosphere $\left(10 \mathrm{~mL} \mathrm{~min}{ }^{-1}\right)$.

\subsection{Milano-type probiotic salami obtained by microencapsulated L. plantarum addition}

\subsubsection{Manufacturing process}

Milano-type salami was produced according to Brazilian regulations (Brazil, 1998, 2000, 2006) following standard formulation (Table 2) described by Krummenauer et al. (2015). Two formulations were obtained: the control salami $\left(\mathrm{F}_{1}\right)$ produced with a commercial starter culture, and the probiotic salami $\left(\mathrm{F}_{2}\right)$ added with microencapsulated L. plantarum, replacing the commercial starter culture. $10 \mathrm{~kg}$-batches were produced for each formulation and divided into ten assay units. Microcapsule addition to $\mathrm{F}_{2}$ was based on the viable cell number in the powder needed to achieve the minimal $8 \log \mathrm{CFU} \mathrm{g}^{-1}$ count in the salami (Brazil, 2008).

Starter culture and L. plantarum microcapsules were previously hydrated in distilled water at $25^{\circ} \mathrm{C}$ for $30 \mathrm{~min}$. Back fat and pork meat were minced using a cutter (Mado, Garant MTK 661, Germany), obtaining particle sizes of approximately 5-8 $\mathrm{mm}$. Dry ingredients and wine were added to the minced meat and manually homogenised. Afterwards, minced back fat and hydrated starter culture of microencapsulated
Table 2

Milano-type salami formulations.

\begin{tabular}{lll}
\hline Raw materials/Ingredients & $\mathrm{F}_{1}(\%)$ & $\mathrm{F}_{2}(\%)$ \\
\hline Pork meat (lean retail) & 76.49 & 76.49 \\
Back fat $^{\mathrm{a}}$ Ibrac Cure & 18.00 & 18.00 \\
Ibracor 501 $^{\mathrm{b}}$ & 0.25 & 0.25 \\
Starter culture Bactoferm SM 1942 $^{\mathrm{c}}$ & 0.30 & 0.30 \\
L. plantarum BG112 microcapsules & 0.04 & - \\
Refined salt & - & 0.10 \\
Crystal sugar & 2.70 & 2.70 \\
White pepper powder & 0.80 & 0.80 \\
Garlic powder & 0.02 & 0.02 \\
Dry red wine & 0.20 & 0.20 \\
Total & 1.20 & 1.20 \\
\hline
\end{tabular}

$\mathrm{F}_{1}$ : Control salami. $\mathrm{F}_{2}$ : Salami added by microencapsulated Lactobacillus plantarum.

Note: The masses of commercial starter culture and microencapsulated probiotic were calculated based on the number of viable cells necessary to provide in salami mass a minimum of $8 \log$ CFU g ${ }^{-1}$, according to ANVISA (Brazil, 2008).

a Composition: salt, sodium nitrite $(6 \%)$, and sodium nitrate $(4 \%)$.

b Composition: sugar, sodium erythorbate and citric acid.

c Combination among the strains of Staphylococcus carnosus, Staphylococcus xylosus, Lactobacillus sakei, Pediococcus pentosaceus, and Debaryomyces hansenii.

L. plantarum were added to the mixture. The salami was stuffed (PCP-10 L, Poli, Brusque, Brazil) in $60 \mathrm{~mm}$ cellulose casings (Naturin R2L-D, Viscofan, São Paulo, Brazil) previously hydrated in distilled water at $25^{\circ} \mathrm{C}$ for $30 \mathrm{~min}$. The salamis were tied with polyester strings and stored for 30 days in a drying and ripening chamber (Refrica, Girona, Spain) located in a meatpacking plant, using conditions similar to those reported by Krummenauer et al. (2015).

\subsubsection{Weight loss and $\mathrm{pH}$ curve determinations}

Weight loss $(W L)$ percentages were determined according to Krummenauer et al. (2015), considering the initial $\left(W_{0}\right)$ and final $\left(W_{1}\right)$ salami weight after ripening.

The $\mathrm{pH}$ was measured using a $\mathrm{pH}$ meter (Testo, Campinas, Brazil) by inserting electrodes in the salami (once a day) for 30 days during ripening. Such analyses were performed in duplicate.

\subsubsection{Centesimal composition and physicochemical properties}

Moisture, lipid, protein, and ash contents of salami formulations were determined in triplicate according to the AOAC (2005) method. Water activity was also performed in triplicate using an Aqualab ${ }^{\circledR}$ analyser (4 TE, São Paulo, Brazil). The salami samples were minced into $5 \pm 2 \mathrm{~mm}$ pieces and analysed at $25 \pm 1{ }^{\circ} \mathrm{C}$. 
$\mathrm{L}^{*}$ (lightness), a*, and b* (CIELAB colour system) colour measurement parameters were determined using a Minolta CR400 colourimeter (Osaka, Japan) with a D65 illuminant and a $10^{\circ}$ standard observer. 10 measurements were carried out on each side of the salami samples.

The samples were cut into $20 \mathrm{~mm}$ cubes for shear force measurements and sheared in triplicate using an HDP/WBV probe with a $2 \mathrm{~mm}$ $\mathrm{s}^{-1}$ test speed coupled to a TA-HD plus texture analyser (Stable Micro Systems, Surrey, UK), fitted with a 5-kg load cell.

\subsubsection{Microbiological evaluation}

The total lactic acid bacteria (LAB) count in salami samples was performed in triplicate, according to Kalschne et al. (2015).

Mesophilic aerobic bacteria (MAB) total count, Salmonella spp., coagulase-positive Staphylococcus, coliforms at $45{ }^{\circ} \mathrm{C}$, and sulfitereducing Clostridia were also determined in triplicate according to methods described by Silva, Junqueira, and Silveira (2010).

\subsubsection{Sensory evaluation}

This study was authorised by the Ethics Committee of the Faculdade Integrado - Campo Mourão-PR, Brazil (certificate number 56836316.2.0000.0092). All panellists gave written consent for the inclusion of material about themselves. The tests were carried out after microbiological evaluation, attesting samples to determine the suitability for consumption as required by ANVISA (Brazil, 2001).

One hundred and forty-one untrained assessors were recruited at Universidade Tecnológica Federal do Paraná, Medianeira Campus, Paraná, Brazil. The assessors, mainly meat products consumers (99.3\%), were university students, lecturers, and employees, aged between 18 and 25 years (80.9\%), 55.3\% female and $44.7 \%$ male, ranging from secondary school to degree level education $(87.2 \%$ undergraduate students). Sensory tests were conducted in individual booths under electrical white lighting in the Sensory Analysis Laboratory. Two salami samples $\left(F_{1}\right.$ and $\left.F_{2}\right)$ were finely sliced and served in coded recipients with three random digits and monadically displayed according to complete balanced block designs in a randomised order. The assessors were instructed to clean their palate with drinking water and salty crackers before and between each sample evaluation. A 10-cm hybrid hedonic scale anchored with verbal terms $(0=$ disliked extremely, $5=$ neither liked, nor disliked, 10 = liked extremely (Villanueva, Petenate, \& Da Silva, 2005) was used to evaluate acceptance (colour, aroma, flavour, texture, and overall impression attributes). The purchase intention of samples was also assessed.

A paired-preference test was also performed serving two salami samples simultaneously and the assessors were asked to choose their preferred one.

\subsection{Statistical analysis}

Yield and encapsulation efficiency (EE) responses were evaluated using Statistica 8.0 software (StatSoft, Tulsa, USA). The adequacy of the second-order models generated was assessed $(\mathrm{p} \leq 0.05)$. The optimal point (assay 12) was experimentally determined. Yield and microencapsulation efficiency were determined and compared with the predicted values for results validation. One-way analysis of variance (ANOVA) and Tukey test at a 5\% (P < 0.05) significance level evaluated the microcapsule physicochemical properties data. Chemical composition and physicochemical properties data from the two salami formulations were evaluated by Student's $t$-test $(\mathrm{P}<0.05)$.

For sensory analyses, the acceptance test was evaluated by a two-way analysis of variance (ANOVA), considering formulations and assessors as the sources of variation, and mean of Tukey test $(\mathrm{P}<0.05)$ was used. The paired-preference test was evaluated according to Roessler, Pangborn, Sidel, and Stone (1978), comparing the minimum number of correct assessments to the minimum number required at a $5 \%$ significance level.

\section{Results and discussion}

\subsection{L. plantarum microencapsulation optimisation}

The microorganism $\left(x_{1}\right)$ and encapsulant $\left(x_{2}\right)$ concentrations used for L. plantarum microencapsulation influenced yield $\left(y_{1}\right)$ and encapsulation efficiency (EE) $\left(y_{2}\right)$ responses. The highest response values were observed at the central points (assays 9, 10, and 11), ranging from $35.8 \%$ to $39.3 \%$ and from $78.2 \%$ to $80.6 \%$ for yield and EE, respectively (Table 1). These experimental conditions corresponded to the $1: 5$ core/ wall ratio. Lower than 1:5 core/wall ratios were not efficient to entrap L. plantarum, suggesting that the polymer content was not enough to cover the microorganism. In contrast, ratios higher than 1:5 resulted in intermediate microencapsulation efficiency values. The L. plantarum cell surface showed hydrophilicity (Kirillova et al., 2017), while Acrycoat S100 is a hydrophobic polymer (Kar et al., 2019). Therefore, when using Acrycoat S100 in higher amounts, interactions amongst the polymer groups, including the methacrylic acid groups (hydrophilic portions), decreased the free groups available for microorganism binding.

The $x_{1}$ and $x_{2}$ quadratic terms had significant adverse effects on responses $(\mathrm{P}<0.05$ ) (Fig. $1 \mathrm{a}$ and $\mathrm{b})$ for both variables. It indicates the existence of maximum $x_{1}$ and $x_{2}$ concentrations to obtain maximum $y_{1}$ and $y_{2}$ responses in the studied range, characterising the optimal point region for $L$. plantarum microencapsulation. The nonsignificant effects were incorporated in the residual. Second-order models were obtained (Fig. 1c and d) for yield and EE, respectively, as a function of L. plantarum and Acrycoat S100 concentrations. The ANOVA F test showed that the models were valid to predict the responses evaluated, where $F_{\text {calculated }}$ (24.5 and 12.6 for yield and EE, respectively) was higher than $\mathrm{F}_{\text {tabulated }}(4.5$ and 4.3 , for yield and $\mathrm{EE}$, respectively), thus generating the response surface, as shown in Fig. 1c and d.

For both responses, the central point region coincided with the optimum Acrycoat S100 and L. plantarum concentrations for yield and EE. The generated models were derivatised for yield and EE. The variables' optimum conditions were estimated to maximise their responses. Therefore, the optimal point for yield was -0.1 for $x_{1}$ (4.72\% Acrycoat S100) and 0.1 for $x_{2}(1.04 \%$ L. plantarum $)$. The optimal point for EE was codified as 0.2 for $x_{1}\left(5.57 \%\right.$ Acrycoat S100) and 0.0 for $\mathrm{x}_{2}(1.00 \%$ L. plantarum). The optimal point determined by this response was considered for method validation since EE represents the microorganism content entrapped within microcapsules. The optimal point (assay 12) was validated considering EE $\left(x_{1}=0.2\right.$ and $\left.x_{2}=0.00\right)$, obtaining $34.9 \%$ and $80.9 \%$ for yield and EE, respectively.

\subsection{L. plantarum microcapsule characterisation}

\subsubsection{Physical characterisation}

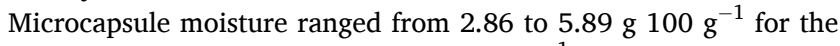

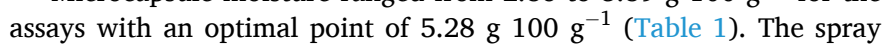
dryer's inlet temperature affects the moisture content of dried powders, and the higher the inlet temperature, the lower the moisture content (Sun, Cameron, \& Bai, 2020). Moisture found in microcapsules maintained bacterial viability during storage, preventing cell death (Eckert et al., 2017).

Water activity ranged from 0.25 to 0.41 , and it was 0.34 for the optimal point assay. The values were within the normal range for spraydried products as described by Eckert et al. (2017). The results were within the recommended limit to ensure microbiological stability $(<0.6)$ (De Castro-Cislaghi, Silva, Fritzen-Freire, Lorenz, \& Sant'Anna, 2012).

Hygroscopicity results varied from 7.64 to $32.65 \mathrm{~g}$ water absorbed per $100 \mathrm{~g}^{-1}$ for the assays. The optimal point was $13.13 \mathrm{~g}$ water absorbed per $100 \mathrm{~g}^{-1}$. Overall, the Acrycoat S100 concentration decrease and the L. plantarum concentration increase were responsible for the higher hygroscopicity values. Such results were due to the lower hydrophilicity of Acrycoat S100 compared to L. plantarum cells, resulting in lower water absorption when Acrycoat S100 and L. plantarum 


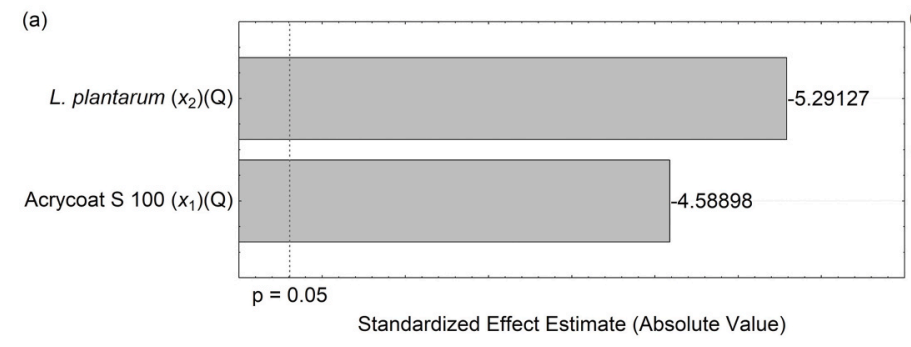

(c)

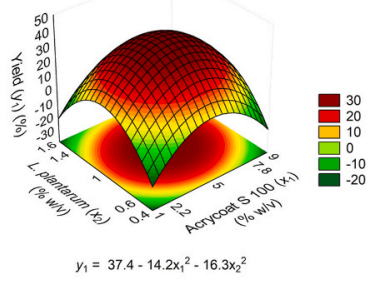

$R^{2}=0.83 ; R$-adjusted $=0.78 ; p<0.0001$

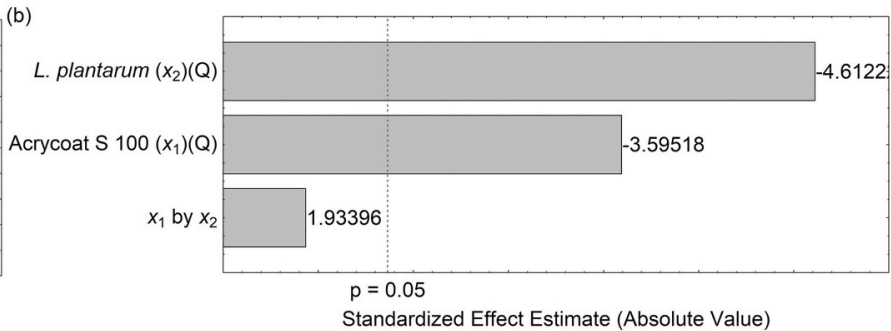

(d)

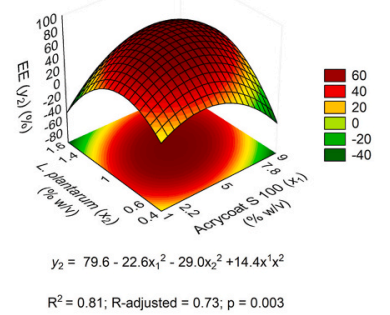

Fig. 1. Pareto chart of effects analysis of Central Composite Rotatable Design for (a) yield $\left(y_{1}\right)$ and (b) encapsulation efficiency ( $\left.y_{2}\right)$; and second-order models and response surface of Central Composite Rotatable Design for (c) yield $\left(y_{1}\right)$ and (d) encapsulation efficiency ( $\left.y_{2}\right)$ of L. plantarum microencapsulated in Acrycoat S100 by spray drying technique.
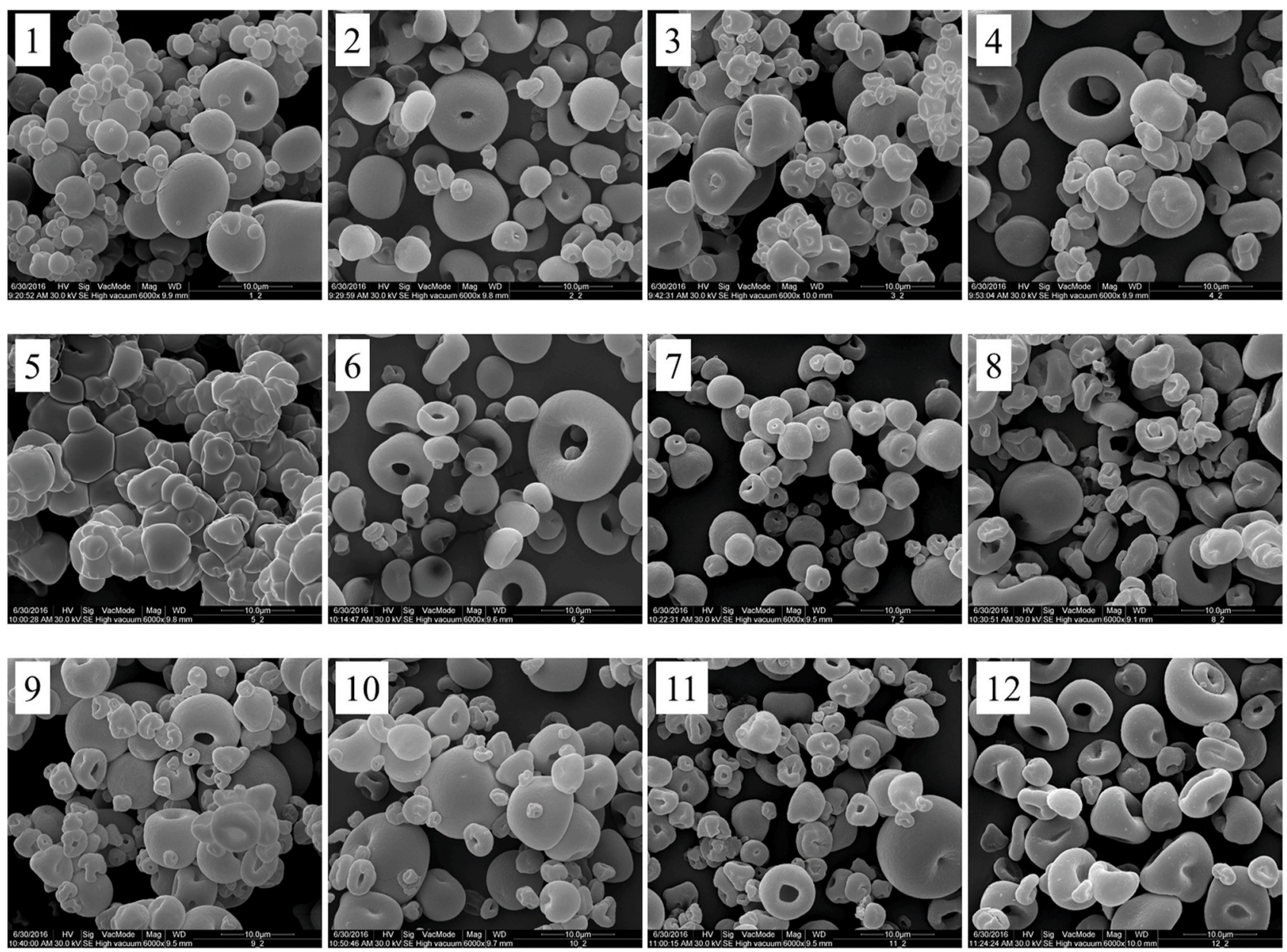

Fig. 2. Morphology of spray-dried microcapsules containing L. plantarum produced with Acrycoat S100. Acrycoat S100 (\%)/L. plantarum (\%): $1=2.2 / 0.6 ; 2=7.8$ / $0.6 ; 3=2.2 / 1.4 ; 4=7.8 / 1.4 ; 5=1.0 / 1.0 ; 6=9.0 / 1.0 ; 7=5.0 / 0.4 ; 8=5.0 / 1.6 ; 9,10$, and $11=5.0 / 1.0 ; 12=5.57 / 1.0$. 
concentrations were inversely proportional.

\subsubsection{Morphology and microcapsule size}

The microcapsules had similar appearances, except for assay 5 (Fig. 2e), irrespective of the $x_{1}$ and $x_{2}$ ratios. The external surfaces had continuous walls free of cracks or shattering, with spherical and oval shapes of various sizes and concavities in the central region. Concavities are typical of spray-drying-produced microcapsules and were attributed to particle shrinkage during the drying process. Khem, Small, and May (2016) also reported concavities on L. plantarum microencapsulation in whey protein isolate. The presence of agglomerates and tiny microcapsules inside larger microcapsules depend on hydrophobic interactions between radicals of the wall material.

The microcapsule size ranged from 4.38 to $6.75 \mu \mathrm{m}$ (Table 1 ) for the assays. Khem et al. (2016) reported similar results (from 1 to $14 \mu \mathrm{m}$ ) for L. plantarum microcapsules with $10 \%$ whey protein isolate as wall material. Such microcapsule size variation is typical of spray-drying-attained powders.

\subsubsection{Fourier transform infrared (FTIR-ATR) spectroscopy}

FTIR-ATR spectra for Acrycoat S100 and free and encapsulated L. plantarum BG112 cells of assays with higher (assays 10 and 12) and lower (assay 5) EE are shown in Fig. 3. Absorption bands at 1725 and $1150 \mathrm{~cm}^{-1}$ were observed in the Acrycoat $\mathrm{S} 100$ spectrum, corresponding to $\mathrm{C}=\mathrm{O}$ characteristic vibrations from carbonyl groups esterified and ester vibrations (C-O) (Mehta, Chawla, Sharma, \& Pawar, 2013). Such wall material vibration bands were also identified in the microcapsule spectra for assays 5,10 , and 12 , suggesting polymer presence in the outer part of microcapsules. However, these bands presented lower intensities in assay 5 than assays 10 and 12 .

FTIR-ATR spectra for viable $L$. plantarum cells presented an absorption band at $1580 \mathrm{~cm}^{-1}$ corresponding to the amide II function and the same was observed in the encapsulated microorganism spectrum. However, assays 10 and 12 presented lower intensity than assay 5 . The polymer content in the assays mentioned above was enough to entrap the microorganism. On the other hand, assay 5 presented more intense bands, suggesting microorganism presence in the outer part of microcapsules. These results corroborated with those observed for EE, with assays $10(80.6 \%)$ and $12(80.9 \%)$ producing microcapsules more efficiently than assay $5(25.3 \%)$. Considering that the FTIR-ATR technique is characterised by surface absorption with low radiation penetration, measurements are related to the outer part of microcapsules. It also

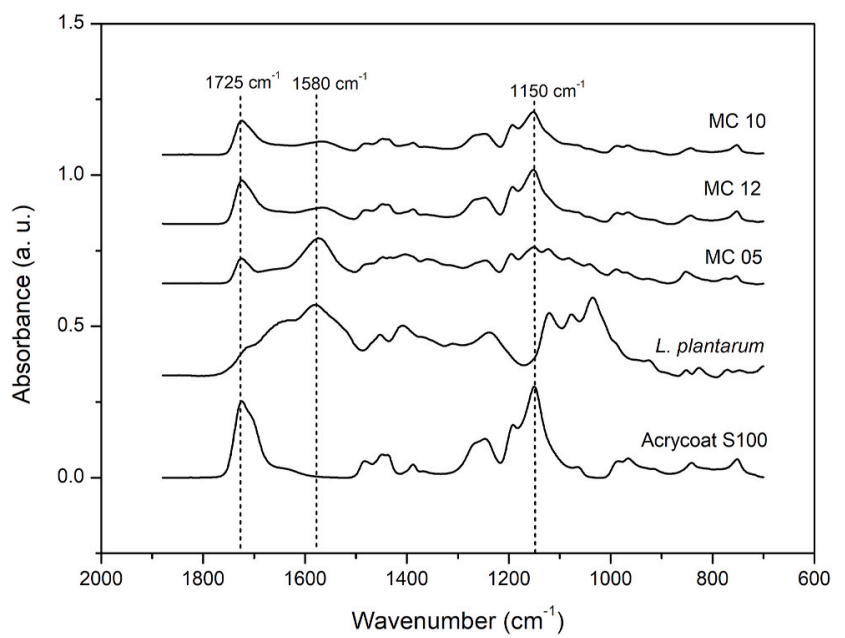

Fig. 3. FTIR-ATR spectra from pure materials (Acrycoat S100 and L. plantarum free cells) and microcapsules corresponding to assays 5 (MC 5, 1.0\% encapsulant and 1.0\% microorganism, w/v), 10 (MC 10, 5.0\% encapsulant and $1.0 \%$ microorganism, w/v), and 12 (MC 12, 6.4\% encapsulant, and 1.0\% microorganism, w/v). justifies the low spectral band intensity referred to microorganisms in the microcapsules with high EE.

\subsubsection{Thermal analyses}

The DTA curve for L. plantarum BG112-free cells (Fig. 4) showed an endothermic peak at $127^{\circ} \mathrm{C}$, which must be due to water ebullition and increased molecular mobility. For Acrycoat S100, a subtle peak was observed at $220^{\circ} \mathrm{C}$, suggesting its melting temperature $\left(\mathrm{T}_{\mathrm{m}}\right)$.

Sharma, Sharma, Panda, and Majumdar (2011) reported $\mathrm{T}_{\mathrm{m}}$ at $216.2^{\circ} \mathrm{C}$ and $188.5^{\circ} \mathrm{C}$ in Eudragit L100 and S100 samples, respectively. They are polymers similar to Acrycoat $\mathrm{S} 100$ and used in papain encapsulation.

No thermal events were observed for L. plantarum encapsulated in assays 5, 10, and 12. Glass transition and melting temperature were not identified in microcapsules, demonstrating their amorphous nature, ensuring encapsulation.

Thermogravimetric curves (TG) (Fig. 5a) showed sample weight loss during the temperature increase. Derivative curves (dTG) from thermogravimetric curves were also determined (Fig. 5b). L. plantarum BG12 free cells thermogravimetric profile did not show any visible separations between the weight loss events. Instead, a continuous process with $27 \%$ residual mass (higher than the encapsulating polymer one) was observed. The differential thermogravimetric (dTG) analysis showed various expected weight loss processes referring to a living organism with a diverse and complex chemical composition. The main weight loss process was observed at a maximum of $130{ }^{\circ} \mathrm{C}$ and $10 \%$ weight loss due to water elimination from the sample. Besides, microorganism weight loss occurred gradually, reaching approximately $25 \%$ at $190{ }^{\circ} \mathrm{C}, 45 \%$ at $285{ }^{\circ} \mathrm{C}$, and $70 \%$ at $478{ }^{\circ} \mathrm{C}$, due to the degradation of proteins, lipids, and polysaccharides found in the microorganism. Acrycoat S100 presented a $10 \%$ weight loss only at $345{ }^{\circ} \mathrm{C}$, observing its degradation temperature at approximately $428{ }^{\circ} \mathrm{C}$. Microcapsules corresponding to assays 10 and 12 exhibited similar dTG behaviour compared to the pure

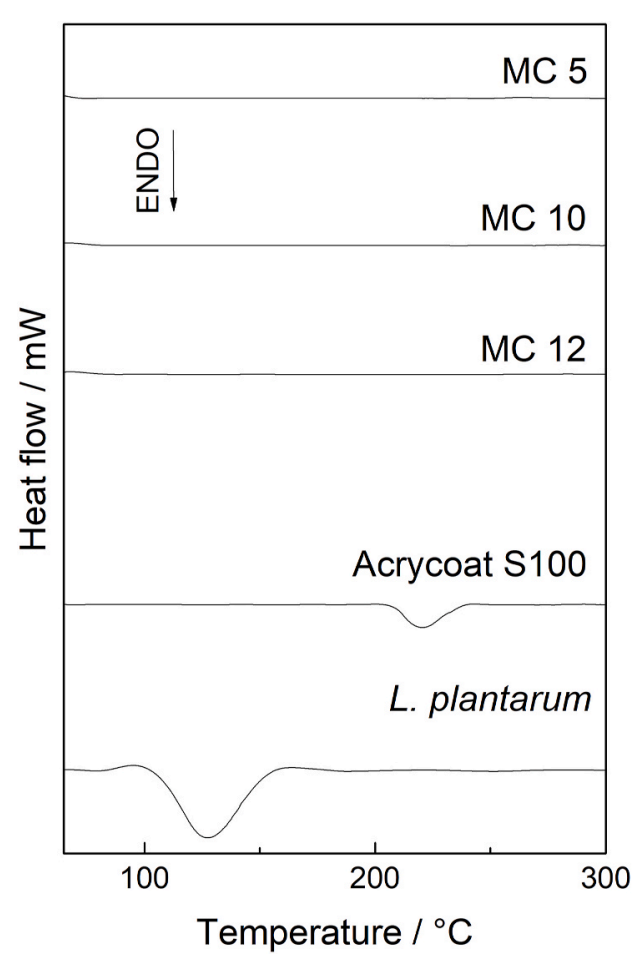

Fig. 4. Differential thermal analysis (DTA) from pure materials (Acrycoat S100 and L. plantarum free cells), and microcapsules corresponding to assays 5 (MC 5 , $1.0 \%$ encapsulant, and $1.0 \%$ microorganism, w/v), 10 (MC 10, 5.0\% encapsulant, and 1.0\% microorganism, w/v), and 12 (MC 12, 6.4\% encapsulant, and $1.0 \%$ microorganism, w/v). 


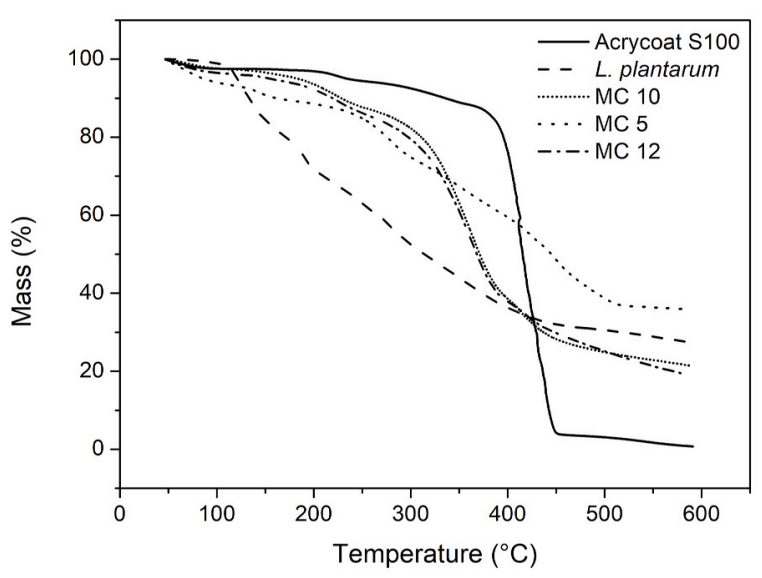

(b)

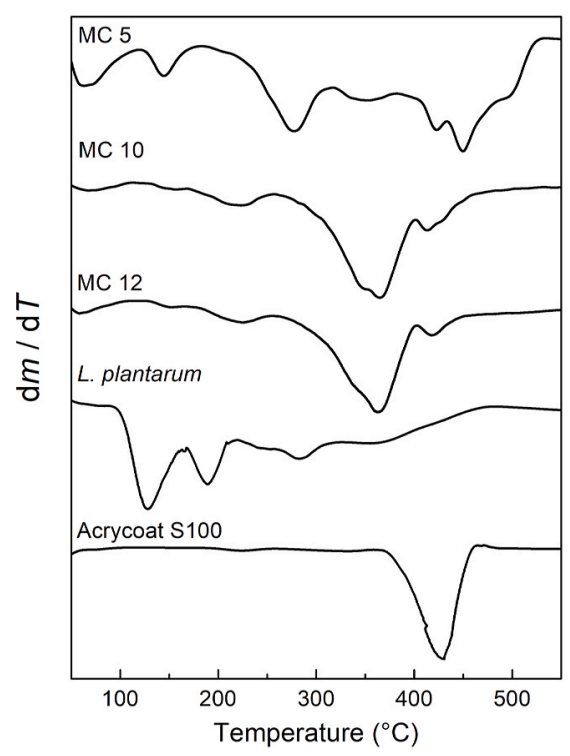

Fig. 5. (a) Thermogravimetric (TG) curves, and (b) their derivative curves (DTG) from pure materials (Acrycoat S100 and L. plantarum free cells), and microcapsules corresponding to assays 5 (MC 5, 1.0\% encapsulant, and 1.0\% microorganism, w/v), 10 (MC 10, 5.0\% encapsulant, and 1.0\% microorganism, $\mathrm{w} / \mathrm{v}$ ) and 12 (MC 12, 6.4\% encapsulant, and 1.0\% microorganism, w/v).

polymer. However, a prominent peak was obtained in the microcapsule dTG curves (assays 10 and 12) ranging from $335{ }^{\circ} \mathrm{C}$ to $365{ }^{\circ} \mathrm{C}$, corresponding to a sharp weight loss. It suggests microcapsule rupture and encapsulated compound degradation. Assay 5 presented a $20 \%$ weight loss for microcapsules at $278{ }^{\circ} \mathrm{C}$, suggesting the presence of microorganisms on their outer part.

\subsection{Milano-type probiotic salami with microencapsulated L. plantarum}

\subsubsection{Chemical and physicochemical characterisation}

Salami weight loss (WL) during ripening is a natural moisture decreasing process caused by controlled drying. WL percentages shown by $F_{1}(37.73 \pm 0.66 \%)$ and $F_{2}(38.95 \pm 1.37 \%)$ salami did not differ from each other and were similar to those found in the literature (Glisic et al., 2019; Krummenauer et al., 2015). The initial and final salami ripening phases were compared and $\mathrm{pH}$ values varied from 5.56 to 5.34 and 5.58 to 5.39 for $F_{1}$ and $F_{2}$, respectively. No significant differences were observed between them during this time. These values are in accordance with those reported by Sameshima et al. (1998) when studying probiotic addition in fermented sausages. The $\mathrm{pH}$ decreases during the ripening phase as a result from lactic acid produced by LAB fermentation. In the present study, the addition of microencapsulated $L$. plantarum replacing starter culture did not cause any changes to the salami $\mathrm{pH}$ decrease during ripening.

$\mathrm{F}_{1}$ and $\mathrm{F}_{2}$ salami chemical compositions (Table 3) were in accordance with the Brazilian legislation for moisture, protein, lipids, and water

Table 3

Chemical, physicochemical, microbiological, and sensory characterization of Milano-type salami formulations produced with a commercial starter culture (F1) or with microencapsulated L. plantarum $\left(\mathrm{F}_{2}\right)$.

\begin{tabular}{|c|c|c|c|c|}
\hline \multicolumn{2}{|l|}{ Salami characterization } & \multirow{2}{*}{$\begin{array}{l}\begin{array}{l}\text { Brazilian } \\
\text { legislation }\end{array} \\
<40\end{array}$} & \multirow{2}{*}{$\begin{array}{l}\mathrm{F}_{1} \\
30.9^{\mathrm{a}} \pm \\
0.7\end{array}$} & \multirow{2}{*}{$\begin{array}{l}\mathrm{F}_{2} \\
30.3^{\mathrm{a}} \pm \\
0.5\end{array}$} \\
\hline $\begin{array}{l}\text { Chemical } \\
\text { composition (g }\end{array}$ & $\begin{array}{l}\text { Moisture (g } 100 \\
\left.g^{-1}\right)\end{array}$ & & & \\
\hline $\left.100 \mathrm{~g}^{-1}\right)$ & $\begin{array}{l}\text { Protein ( } \mathrm{g} 100 \\
\mathrm{~g}^{-1} \text { ) }\end{array}$ & $>20$ & $\begin{array}{l}31.3^{\mathrm{a}} \pm \\
0.5\end{array}$ & $\begin{array}{l}30.6^{\mathrm{a}} \pm \\
0.6\end{array}$ \\
\hline & Lipid $\left(g 100 g^{-1}\right)$ & $<35$ & $\begin{array}{l}29.5^{\mathrm{a}} \pm \\
1.7\end{array}$ & $\begin{array}{l}28.9^{\mathrm{a}} \pm \\
0.4\end{array}$ \\
\hline & Ash $\left(g 100 g^{-1}\right)$ & - & $\begin{array}{l}6.9^{\mathrm{a}} \pm \\
0.2\end{array}$ & $\begin{array}{l}6.5^{\mathrm{a}} \pm \\
0.1\end{array}$ \\
\hline \multirow[t]{8}{*}{$\begin{array}{l}\text { Physicochemical } \\
\text { properties }\end{array}$} & $\begin{array}{l}\text { Weight loss (WL) } \\
(\%)\end{array}$ & - & $\begin{array}{l}37.73^{\mathrm{a}} \pm \\
0.66\end{array}$ & $\begin{array}{l}38.95^{\mathrm{a}} \pm \\
1.37\end{array}$ \\
\hline & $\mathrm{pH}$ initial & - & $\begin{array}{l}5.56^{\mathrm{a}} \pm \\
0.02\end{array}$ & $\begin{array}{l}5.58^{\mathrm{a}} \pm \\
0.03\end{array}$ \\
\hline & $\mathrm{pH}$ final & - & $\begin{array}{l}5.34^{\mathrm{a}} \pm \\
0.01\end{array}$ & $\begin{array}{l}5.39^{\mathrm{a}} \pm \\
0.05\end{array}$ \\
\hline & Water activity & $<0.92$ & $\begin{array}{l}0.86^{\mathrm{a}} \pm \\
0.00\end{array}$ & $\begin{array}{l}0.84^{\mathrm{a}} \pm \\
0.00\end{array}$ \\
\hline & $L^{*}$ & - & $\begin{array}{l}45.60^{\mathrm{a}} \pm \\
1.48\end{array}$ & $\begin{array}{l}42.93^{\mathrm{a}} \pm \\
3.39\end{array}$ \\
\hline & $a^{*}$ & - & $\begin{array}{l}12.09^{\mathrm{a}} \pm \\
0.82\end{array}$ & $\begin{array}{l}10.62^{\mathrm{a}} \pm \\
1.43\end{array}$ \\
\hline & $b^{*}$ & - & $\begin{array}{l}8.77^{\mathrm{a}} \pm \\
0.63\end{array}$ & $\begin{array}{l}9.75^{\mathrm{a}} \pm \\
0.80\end{array}$ \\
\hline & Shear force $(\mathrm{N})$ & - & $\begin{array}{l}27.8^{\mathrm{a}} \pm \\
11.4\end{array}$ & $\begin{array}{l}29.8^{\mathrm{a}} \pm \\
9.5\end{array}$ \\
\hline \multirow{6}{*}{$\begin{array}{l}\text { Microbiological } \\
\text { analyses (log CFU } \\
\mathrm{g}^{-1} \text { ) }\end{array}$} & $\begin{array}{l}\text { Salmonella spp. } \\
\text { (in } 25 \mathrm{~g} \text { ) }\end{array}$ & Absence & Absence & Absence \\
\hline & $\begin{array}{l}\text { Coagulase } \\
\text { positive } \\
\text { Staphylococcus }\end{array}$ & $<3.7$ & $<2$ & $<2$ \\
\hline & $\begin{array}{l}\text { Coliforms at } \\
45^{\circ} \mathrm{C}\end{array}$ & $<3$ & $<1$ & $<1$ \\
\hline & $\begin{array}{l}\text { Sulfite reducing } \\
\text { Clostridia }\end{array}$ & $<2.7$ & $<1$ & $<1$ \\
\hline & Total LAB & - & 5 & 8 \\
\hline & Total MAB & - & 8 & 8 \\
\hline \multirow[t]{6}{*}{$\begin{array}{l}\text { Sensory test hedonic } \\
\text { scale }\end{array}$} & Colour & - & $\begin{array}{l}7.0^{\mathrm{a}} \pm \\
2.0\end{array}$ & $\begin{array}{l}6.8^{\mathrm{a}} \pm \\
1.7\end{array}$ \\
\hline & Aroma & - & $\begin{array}{l}7.0^{\mathrm{a}} \pm \\
2.0\end{array}$ & $\begin{array}{l}7.2^{\mathrm{a}} \pm \\
1.8\end{array}$ \\
\hline & Flavour & - & $\begin{array}{l}7.6^{\mathrm{a}} \pm \\
1.9\end{array}$ & $\begin{array}{l}7.6^{\mathrm{a}} \pm \\
1.7\end{array}$ \\
\hline & Texture & - & $\begin{array}{l}7.7^{\mathrm{a}} \pm \\
1.7\end{array}$ & $\begin{array}{l}7.6^{\mathrm{a}} \pm \\
1.7\end{array}$ \\
\hline & $\begin{array}{l}\text { Overall } \\
\text { acceptance }\end{array}$ & - & $\begin{array}{l}7.7^{\mathrm{a}} \pm \\
1.6\end{array}$ & $\begin{array}{l}7.6^{\mathrm{a}} \pm \\
1.5\end{array}$ \\
\hline & $\begin{array}{l}\text { Purchase } \\
\text { intention }\end{array}$ & - & $\begin{array}{l}7.4^{\mathrm{a}} \pm \\
1.9\end{array}$ & $\begin{array}{l}7.4^{\mathrm{a}} \pm \\
1.9\end{array}$ \\
\hline \multirow{6}{*}{$\begin{array}{l}\text { Sensory acceptance } \\
\text { index (\%) }\end{array}$} & Colour & - & 70 & 68 \\
\hline & Aroma & - & 70 & 72 \\
\hline & Flavour & - & 76 & 76 \\
\hline & Texture & - & 77 & 76 \\
\hline & $\begin{array}{l}\text { Overall } \\
\text { acceptance }\end{array}$ & - & 77 & 76 \\
\hline & $\begin{array}{l}\text { Purchase } \\
\text { intention }\end{array}$ & - & 74 & 74 \\
\hline
\end{tabular}

LAB: lactic acid bacteria. MAB: Mesophilic aerobic bacteria.

Mean \pm standard deviation. Different letters in the same row indicate significant differences by the Student $t$-test $(\mathrm{P} \leq 0.05)$ for chemical and physicochemical determinations $(n=3)$ and by the Tukey test $(P \leq 0.05)$ for the hedonic scale test $(n=141)$.

Brazilian legislations: Brazil (2000; 2001). 
activity (Brazil, 2000) and did not differ between the formulations. These results confirmed raw material standardisation and that L. plantarum microcapsules addition did not affect the salami composition.

Colour measurement values (Table 3 ) did not differ between the $\mathrm{F}_{1}$ and $\mathrm{F}_{2}$ formulations. The $\mathrm{L}^{*}$ colour parameter (lightness) varied from $45.60\left(\mathrm{~F}_{1}\right)$ to $42.93\left(\mathrm{~F}_{2}\right)$ and was similar to that reported by Ruiz, Villanueva, Favaro-Trindade, and Contreras-Castillo (2014), who studied salami with different starter cultures. The $\mathrm{a}^{*}$ (redness) parameter values varied from $12.09\left(\mathrm{~F}_{1}\right)$ to $10.62\left(\mathrm{~F}_{2}\right)$ and were directly connected to salami curing and ripening. During these processes, myoglobin interacts with nitric oxide, producing nitrosomyoglobin, typical of cured meat. For the $b^{*}$ parameter (yellowness), the values varied from $8.77\left(F_{1}\right)$ to $9.75\left(\mathrm{~F}_{2}\right)$. According to Pérez-Alvarez, Sayas-Barberá, Fernández-López, and Aranda-Catalá (1999), b* values changes (increase/decrease) relate to oxygen consumption by microbial cultures inserted in the meat product, both probiotic and starter, during their exponential growth phase. The $a^{*}$ and $b^{*}$ values obtained in the present study were in accordance with those reported by Campagnol, Fries, Terra, Santos, and Furtado (2007) and Ruiz et al. (2014), who studied potentially probiotic salami.

Shear force values did not differ between the salami formulations, varying from $27.8 \mathrm{~N}\left(\mathrm{~F}_{1}\right)$ to $29.8 \mathrm{~N}\left(\mathrm{~F}_{2}\right)$, similar to that reported by Daengprok, Garnjanagoonchorn, and Mine (2002) and Xing et al. (2015) who studied fermented sausages.

Salami formulations were in accordance with the Brazilian legislation for microbiological analysis (Brazil, 2001) (Table 3). The microbiological quality of cured meat products may be evaluated based on microbial groups such as mesophilic aerobic bacteria (MAB) and coliforms at $45{ }^{\circ} \mathrm{C}$ (used as indicators). For MAB count, $8 \log \mathrm{CFU} \mathrm{g} \mathrm{g}^{-1}$ values were obtained for both formulations, and coliforms at $45{ }^{\circ} \mathrm{C}$ counts were lower than $1 \log \mathrm{CFU} \mathrm{g}{ }^{-1}$. These counts, typical for this type of fermented sausage, do not represent microbial alteration (Menéndez, Rendueles, Sanz, Santos, \& García-Fernández, 2018).

The LAB count was higher in $\mathrm{F}_{2}\left(8 \log \mathrm{CFU} \mathrm{g}{ }^{-1}\right)$ than in $\mathrm{F}_{1}(5 \log \mathrm{CFU}$ $\left.\mathrm{g}^{-1}\right) . \mathrm{F}_{1}$ values were in accordance with the Brazilian legislation (Brazil, 2008), which suggests counts higher than $8 \mathrm{CFU} \mathrm{g}{ }^{-1}$ for probiotic product characterisation. Coman et al. (2012) also reported 8 log CFU $\mathrm{g}^{-1}$ counts in probiotic salami with combined Lactobacillus strains. The results obtained in the present study showed that $L$. plantarum microcapsules added to salami dominated endogenous LAB during the fermentation process. It is due to the presence of non-encapsulated microorganisms adhered to the microcapsule's surface. Despite the probiotic property, higher LAB counts could contribute to the safety and microbiological stability of the salami produced. This protective effect is due to bacteriocins, which are capable of inhibiting pathogenic and deteriorating bacteria.

\subsubsection{Sensory evaluation}

$F_{1}$ and $F_{2}$ salami formulations did not differ from each other when evaluated by a 10-point hedonic scale test for colour, aroma, flavour, texture, overall acceptance, and purchase intention attributes (Table 3). Taking into account the $70 \%$ acceptance index (minimum limit) (Teixeira, Meinert, \& Barbetta, 1987), the acceptance indexes calculated for colour, aroma, flavour, texture, overall acceptance, and purchase intention from samples demonstrated good acceptance for all attributes (Table 3). The results indicated that both samples were accepted and L. plantarum microcapsules addition did not influence product acceptance. The results from the present study were similar to those found by (Ruiz et al., 2014), who reported no sensorial acceptance differences between the salami produced with commercial starter and the ones with probiotic cultures. Campagnol et al. (2007) reported that probiotic culture addition improved the salami flavour compared to the commercial starter culture. Similar acceptance results were reported by Cavalheiro et al. (2019), who studied the use of encapsulated L. plantarum in dry fermented chorizo compared to a control sample (without probiotic).

82 assessors preferred the $\mathrm{F}_{2}$ sample in the paired-preference test. According to Roessler et al. (1978), 83 assessments are minimally required for a sample to be regarded the preferred one ( $\mathrm{n}=141, \alpha=$ 0.05 ). Therefore, the paired-preference test confirmed that the samples did not differ from each other.

\section{Conclusion}

Lactobacillus plantarum was efficiently microencapsulated in Acrycoat S100 by spray drying and an optimal formulation was obtained considering the highest encapsulation efficiency. Moreover, Milano-type probiotic salami with microencapsulated $L$. plantarum was obtained. The microorganism resisted the fermentation and ripening phases, demonstrating its advantages as a probiotic product since Acrycoat S100 has a $\mathrm{pH}$-dependent controlled release $(\mathrm{pH}>7.0)$. No sensory acceptance differences were noticed between the batch added with starter culture and that with microencapsulated L. plantarum. L. plantarum microcapsule addition did not influence the product's sensory characteristics, having good consumer acceptance. Furthermore, the thermal stability demonstrated by L. plantarum microcapsules may expand its application to other food matrices requiring heat treatment for their processing.

\section{CRediT authorship contribution statement}

Lia Inês Machado Vasconcelos: Validation, Formal analysis, Data curation. Rosana Aparecida da Silva-Buzanello: Methodology, Validation, Formal analysis, Data curation, Writing - original draft, Visualization. Daneysa Lahis Kalschne: Methodology, Validation, Formal analysis, Data curation, Writing - original draft, Visualization. Fernando Reinoldo Scremin: Investigation, Data curation, Writing - review \& editing. Paulo Rodrigo Stival Bittencourt: Investigation, Resources, Writing - review \& editing, Funding acquisition. Joaquina Teresa Gaudêncio Dias: Term and conceptualization, Writing - review \& editing, Supervision, Project administration, Funding acquisition. Cristiane Canan: Term and conceptualization, Methodology, Resources, Writing - original draft, Visualization, Supervision, Project administration, Funding acquisition. Marinês Paula Corso: Term and conceptualization, Methodology, Resources, Writing - original draft, Visualization, Supervision, Project administration, Funding acquisition.

\section{Declaration of competing interest}

The authors declare that they have no known competing financial interests or personal relationships that could have appeared to influence the work reported in this paper.

\section{Acknowledgements}

This study was financed in part by the Coordenação de Aperfeiçoamento de Pessoal de Nível Superior - Brasil (CAPES) -Finance Code 001, $\mathrm{CNPq}$, and Fundação Araucária.

\section{References}

Ambalam, P., Raman, M., Purama, R. K., \& Doble, M. (2016). Probiotics, prebiotics and colorectal cancer prevention. Best Practice \& Research Clinical Gastroenterology, 30(1), 119-131. https://doi.org/10.1016/j.bpg.2016.02.009

Aoac. (2005). Official methods of analysis of the association of official analytical chemists (18th ed.). Arlington: AOAC.

Aspri, M., Papademas, P., \& Tsaltas, D. (2020). Review on non-dairy probiotics and their use in non-dairy based products. Fermentatio, 6(1), 1-20. https://doi.org/10.3390/ fermentation6010030

Basu, S., Banerjee, D., Chowdhury, R., \& Bhattacharya, P. (2018). Controlled release of microencapsulated probiotics in food matrix. Journal of Food Engineering, 238, 61-69. https://doi.org/10.1016/j.jfoodeng.2018.06.005

Brazil. (1998). Regulamento Técnico da Inspeção Tecnológica e Higiênico-Sanitária de Carne de Aves. In , Portaria n 210 de 10 de novembro de 1998. Brasília, Brazil: Diário Oficial da UniãoMinistério da Agricultura Pecuária e Abastecimento. 
Brazil. (2000). Regulamentos Técnicos de Identidade e Qualidade de Copa, de Jerked Beef, de Presunto tipo Parma, de Presunto Cru, de Salame, de Salaminho, de Salame tipo Alemão, de Salame tipo Calabres, de Salame tipo Friolano. de Salame tipo Napolitano, de Salame tipo H. Instrução Normativa $N^{\circ} 22$ de 31/07/2000. Retrieved from http://www.enge tecno.com.br/legislacao/carnes salame.htm.

Brazil. (2001). Regulamento Técnico sobre Padrões Microbiológicos para Alimentos. In Ministério da Saúde. Agência Nacional de Vigilância Sanitária. In Resolução RDC $n^{\circ}$ 12, de 02 de janeiro de 2001. Brasília, Brazil: Diário Oficial da União.

Brazil. (2006). Regulamento Técnico de Atribuição de Aditivos, e seus Limites das seguintes Categorias de Alimentos 8: Carne e Produtos Cárneos. Instrução Normativa $N^{\circ} 51$ de 29/ 12/2006. Brasília: Diário Oficial da União.

Brazil. (2008). Alimentos com Alegações de Propriedades Funcionais e ou de Saúde, Novos Alimentos/Ingredientes, Substâncias Bioativas e Probióticos. In M. da Saúde (Ed.), IX - Lista de alegações de propriedade funcional aprovadas. Brasília, Brazil: Agência Nacional de Vigilância Sanitária.

Bultosa, G. (2015). Functional foods: Dietary fibers, prebiotics, probiotics, and synbiotics. In Encyclopedia of food grains: 2nd ed. (2nd ed., Vols. 2-4). https://doi. org/10.1016/B978-0-12-394437-5.00245-X

Campagnol, P. C. B., Fries, L. L. M., Terra, N. N., Santos, B. A., \& Furtado, A. S. (2007). Salame elaborado com Lactobacillus plantarum fermentado em meio de cultura de plasma suíno. Ciência e Tecnologia de Alimentos, 27(4), 883-889. https://doi.org/ 10.1590/S0101-20612007000400032

Cavalheiro, C. P., Ruiz-Capillas, C., Herrero, A. M., Jiménez-Colmenero, F., Pintado, T. de Menezes, C. R., et al. (2019). Effect of different strategies of Lactobacillus plantarum incorporation in chorizo sausages. Journal of the Science of Food and Agriculture, 99(15), 6706-6712. https://doi.org/10.1002/jsfa.9952

Colomé, L. M., Raffin, R. P., Jornada, D. S., Pohlmann, A. R., \& Guterres, S. S. (2007) Pantoprazole-loaded Eudragit blended microparticles: Preparation, characterization, in vitro gastro-resistance and in vivo anti-ulcer evaluation. Journal of Drug Delivery Science and Technology, 17(2), 113-118. https://doi.org/10.1016/S1773-2247(07) 50017-1

Coman, M. M., Cecchini, C., Verdenelli, M. C., Silvi, S., Orpianesi, C., \& Cresci, A. (2012)

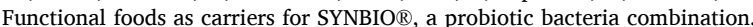
International Journal of Food Microbiology, 157(3), 346-352. https://doi.org/ 10.1016/j.ijfoodmicro.2012.06.003

Daengprok, W., Garnjanagoonchorn, W., \& Mine, Y. (2002). Fermented pork sausage fortified with commercial or hen eggshell calcium lactate. Meat Science, 62(2), 199-204. https://doi.org/10.1016/S0309-1740(01)00247-9

De Castro-Cislaghi, F. P., Silva, C. D. R. E., Fritzen-Freire, C. B., Lorenz, J. G., \& Sant'Anna, E. S. (2012). Bifidobacterium Bb-12 microencapsulated by spray drying with whey: Survival under simulated gastrointestinal conditions, tolerance to $\mathrm{NaCl}$, and viability during storage. Journal of Food Engineering, 113(2), 186-193. https:// doi.org/10.1016/j.jfoodeng.2012.06.006

Dubey, V., Ghosh, A. R., Bishayee, K., \& Khuda-Bukhsh, A. R. (2016). Appraisal of the anti-cancer potential of probiotic Pediococcus pentosaceus GS4 against colon cancer: In vitro and in vivo approaches. Journal of Functional Foods, 23, 66-79. https://doi. org/10.1016/j.jff.2016.02.032

Eckert, C., Serpa, V. G., Felipe dos Santos, A. C., Marinês da Costa, S., Dalpubel, V., Lehn, D. N., et al. (2017). Microencapsulation of Lactobacillus plantarum ATCC 8014 through spray drying and using dairy whey as wall materials. LebensmittelWissenschaft und-Technologie- Food Science and Technology, 82, 176-183. https://doi. org/10.1016/j.lwt.2017.04.045

FAO, \& WHO. (2006). Probióticos en los alimentos Propiedades saludables y nutricionales y directrices para la evaluación (Vol. 85, p. 52). Estudios FAO Alimentación y Nutrición. Retrieved from http://www.fao.org/3/a0512s/a0512s00.pdf.

Fritzen-Freire, C. B., Prudêncio, E. S., Amboni, R. D. M. C., Pinto, S. S., NegrãoMurakami, A. N., \& Murakami, F. S. (2012). Microencapsulation of bifidobacteria by spray drying in the presence of prebiotics. Food Research International, 45(1), 306-312. https://doi.org/10.1016/j.foodres.2011.09.020

Glisic, M., Baltic, M., Glisic, M., Trbovic, D., Jokanovic, M., Parunovic, N., et al. (2019). Inulin-based emulsion-filled gel as a fat replacer in prebiotic- and PUFA-enriched dry fermented sausages. International Journal of Food Science and Technology, 54(3), 787-797. https://doi.org/10.1111/ijfs.13996

Kalschne, D. L., Womer, R., Mattana, A., Sarmento, C. M. P., Colla, L. M., \& Colla, E. (2015). Characterization of the spoilage lactic acid bacteria in "sliced vacuumpacked cooked ham". Brazilian Journal of Microbiology, 46(1), 173-181. https://doi. org/10.1590/S1517-838246120130019

Kar, A. K., Majumder, T., Majumdar, S., Mahanti, B., Kar, B., Chakraborty, S., et al. (2019). Design, formulation and evaluation of sustained release bilayer tablets of ciprofloxacin hydrochloride. Journal of Drug Delivery and Therapeutics, 9(1), 46-53. https://doi.org/10.22270/jddt.v9i1.2158
Khem, S., Small, D. M., \& May, B. K. (2016). The behaviour of whey protein isolate in protecting Lactobacillus plantarum. Food Chemistry, 190, 717-723. https://doi.org/ 10.1016/j.foodchem.2015.06.020

Kirillova, A. V., Danilushkina, A. A., Irisov, D. S., Bruslik, N. L., Fakhrullin, R. F., Zakharov, Y. A., et al. (2017). Assessment of resistance and bioremediation ability of Lactobacillus strains to lead and cadmium. International Journal of Microbiology. https://doi.org/10.1155/2017/9869145, 2017.

Krummenauer, E. P., Paranhos, G. O., Silva, J. F., Silva-Buzanello, R. A., Kalschne, D. L., Corso, M. P., et al. (2015). Salame tipo Milano com substituição parcial do toucinho por queijo mussarela. Revista Cultivando o Saber, 8(2), 143-161.

Mehta, R., Chawla, A., Sharma, P., \& Pawar, P. (2013). Formulation and in vitro evaluation of Eudragit S-100 coated naproxen matrix tablets for colon-targeted drug delivery system. "Journal of Advanced Pharmaceutical Technology \& Research"'"', 4(1), 31. https://doi.org/10.4103/2231-4040.107498

Menéndez, R. A., Rendueles, E., Sanz, J. J., Santos, J. A., \& García-Fernández, M. C. (2018). Physicochemical and microbiological characteristics of diverse Spanish cured meat products. CyTA - Journal of Food, 16(1), 199-204. https://doi.org/ 10.1080/19476337.2017.1379560

Menezes, L. A. A., Matias de Almeida, C. A., Mattarugo, N. M. de S., Ferri, E. A. V., Bittencourt, P. R. S., Colla, E., et al. (2018). Soy extract and maltodextrin as microencapsulating agents for Lactobacillus acidophilus: A model approach. Journal of Microencapsulation, 35(7-8), 705-719. https://doi.org/10.1080/ 02652048.2019.1579264

Pavli, F. G., Argyri, A. A., Chorianopoulos, N. G., Nychas, G. J. E., \& Tassou, C. C. (2020). Effect of Lactobacillus plantarum L125 strain with probiotic potential on physicochemical, microbiological and sensorial characteristics of dry-fermented sausages. Lebensmittel-Wissenschaft und -Technologie- Food Science and Technology, 118, 108810. https://doi.org/10.1016/j.lwt.2019.108810. November 2019.

Pérez-Alvarez, J. A., Sayas-Barberá, M. E., Fernández-López, J., \& Aranda-Catalá, V. (1999). Physicochemical characteristics of Spanish-type dry-cured sausage. Food Research International, 32(9), 599-607. https://doi.org/10.1016/S0963-9969(99) 00104-0

Picot, A., \& Lacroix, C. (2004). Encapsulation of bifidobacteria in whey protein-based microcapsules and survival in simulated gastrointestinal conditions and in yoghurt. International Dairy Journal, 14(6), 505-515. https://doi.org/10.1016/j. idairyj.2003.10.008

Roessler, E. B., Pangborn, R. M., Sidel, J. L., \& Stone, H. (1978). Expanded statistical tables for estimating significance in paired-preference, paired-difference, duo-trio and triangle tests. Journal of Food Science, 43.

Ruiz, J. N., Villanueva, N. D. M., Favaro-Trindade, C. S., \& Contreras-Castillo, C. J. (2014). Physicochemical, microbiological and sensory assessments of Italian salami sausages with probiotic potential. Scientia Agricola, 71(3), 204-211. https://doi.org/ 10.1590/S0103-90162014000300005

Sameshima, T., Magome, C., Takeshita, K., Arihara, K., Itoh, M., \& Kondo, Y. (1998). Effect of intestinal Lactobacillus starter cultures on the behaviour of Staphylococcus aureus in fermented sausage. International Journal of Food Microbiology, 41(1), 1-7. https://doi.org/10.1016/S0168-1605(98)00038-5

Sharma, M., Sharma, V., Panda, A. K., \& Majumdar, D. K. (2011). Development of enteric submicron particle formulation of papain for oral delivery. International Journal of Nanomedicine, 6, 2097-2111. https://doi.org/10.2147/IJN.S23985

Silva, N., Junqueira, V. C. A., \& Silveira, N. F. A. (2010). Manual de métodos de Análise microbiológica de Alimentos (3. São Paulo, Brazil: Varela.

Sun, X., Cameron, R. G., \& Bai, J. (2020). Effect of spray-drying temperature on physicochemical, antioxidant and antimicrobial properties of pectin/sodium alginate microencapsulated carvacrol. Food Hydrocolloids, 100, 105420. https://doi. org/10.1016/j.foodhyd.2019.105420. July 2019.

Teixeira, E., Meinert, E. M., \& Barbetta, P. A. (1987). Análise Sensorial de alimentos. Florianópolis. UFSC.

Villanueva, N. D. M., Petenate, A. J., \& Da Silva, M. A. A. P. (2005). Performance of the hybrid hedonic scale as compared to the traditional hedonic, self-adjusting and ranking scales. Food Quality and Preference, 16(8), 691-703. https://doi.org/ 10.1016/j.foodqual.2005.03.013

Xing, Y., Xu, Q., Jiang, L., Cao, D., Lin, H., Che, Z., et al. (2015). Effect of different coating materials on the biological characteristics and stability of microencapsulated Lactobacillus acidophilus. RSC Advances, 5(29), 22825-22837. https://doi.org/ 10.1039/c4ra13578d

Yao, M., Xie, J., Du, H., McClements, D. J., Xiao, H., \& Li, L. (2020). Progress in microencapsulation of probiotics: A review. Comprehensive Reviews in Food Science and Food Safety, 19(2), 857-874. https://doi.org/10.1111/1541-4337.12532 